Acknowledgements. We thank the seismic crew with Craig Milne and John Jaeger as co-ordinators, the crew of R/V Western Arctic, the helicopter crew of OY-HSA, Ken Henderson of Exploration Consultants Ltd., Torben Clausen of the Danish Meteorological Institute and Poul S. Hansen of the Danish Hydraulic Institute for their co-operation during the very successful field operations. We especially thank the captain Peter Lund Nielsen for his tireless efforts during ice operations.

The NAD project is funded by the European Economic Community and by the Danish Ministry of Energy.

\title{
References
}

Andersen, M. S., Larsen, H. C., Risum, J. B. \& Thorning, L. 1981: Geophysical investigations offshore East Greenland - Project NAD. Rapp. Gronlands geol. Unders. 105, 56-60.

Larsen, H. C. \& Andersen, M. S. 1982: Marine geophysical investigations offshore East Greenland. Rapp. Gronlands geol. Unders. 110, 81-86.

Larsen, H. C. \& Thorning, L. 1980: Project EASTMAR: acquisition of high sensitivity aeromagnetic data off East Greenland. Rapp. Grønlands geol. Unders. 100, 91-94.

Risum, J. B. 1980: Project NAD - Part 2: a marine geophysical project offshore East Greenland. Rapp. Gronlands geol. Unders. 100, 99-101.

\section{Glaciology related to potential hydroelectric power for Greenland towns}

\section{Anker Weidick and Henrik Højmark Thomsen}

There is increasing interest in the possibility of supplying towns with hydroelectric power from neighbouring basins. To meet this interest the project 'Vandkraftundersøgelser for bynære bassiner' was carried out at the localities listed in Table 4 and shown in figure 37 . The project has been in operation since 1980 as a joint project of Greenland Fisheries Investigations and the Greenland Technical Organization; in 1982 GGU commenced glaciological work on the project. The project is due to terminate in March 1984.

The effect of glaciers upon the discharge from the individual basins must vary greatly according to glacier cover but it can rarely be neglected and is of paramount importance for basins receiving meltwater from the Inland Ice.

The objective of the investigation is the determination of the relations between local climatic conditions, mass balance, and variations in the discharge of the individual glaciers. The basic requirement therefore is to list glacier areas, elevations and types, together with information on recent changes in their extent and form. An inventory of all the basins with this information, together with a review of current base maps, has been made. The subsequent steps in the determination of the individual mass balance conditions on the basis of snow line altitudes and the data transferred from meteorological and glaciological stations is in progress. For the glaciological work the results are based on measurements at selected glaciers (Johan Dahl Land, Taseq, Qamanârssûp sermia, Qapiarfiup sermia and Tasersiaq) the locations of which are shown in figure 37 . In the light of the geographical spread of the 


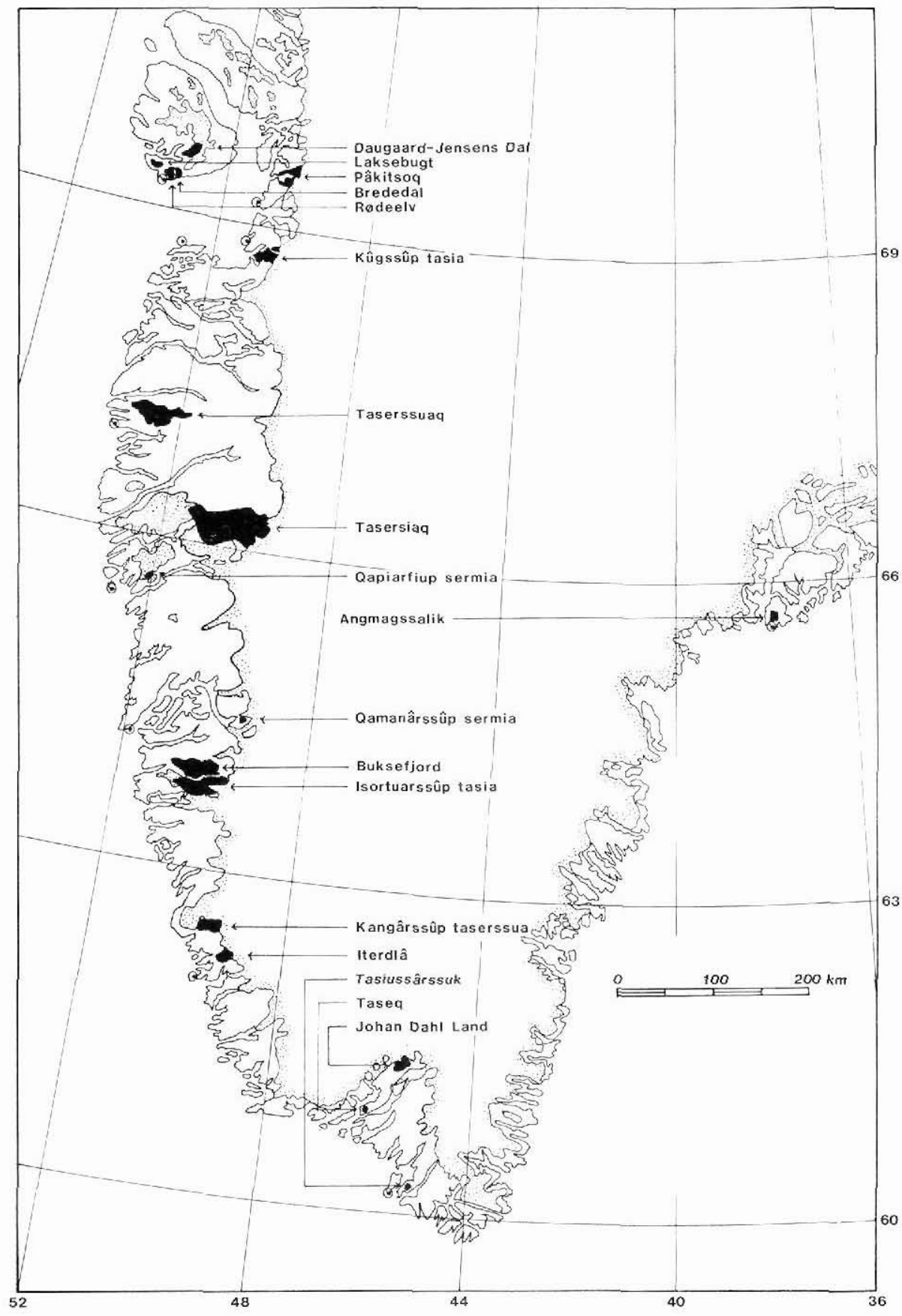

Fig. 37. Map of localities for hydropower investigations. 
Table 4. List of localities for inventory of the project 'Vandkraftundersøgelser for bynare bassiner'

\begin{tabular}{|c|c|c|c|c|}
\hline Name of locality & $\begin{array}{l}\text { Number of } \\
\text { local glaciers }\end{array}$ & $\begin{array}{l}\text { Total area of } \\
\text { local glaciers } \\
\text { in } \mathrm{km}^{2}\end{array}$ & $\begin{array}{l}\text { Local glaciers } \\
\text { as \% of total } \\
\text { basin area }\end{array}$ & $\begin{array}{l}\text { Lobes from the } \\
\text { Inland Ice }\end{array}$ \\
\hline $\begin{array}{l}\text { Tasiussârssuk } \\
\text { Taseq } \\
\text { Iterdlâ } \\
\text { Kangârssâp taserssua } \\
\text { Isortuarssap tasia } \\
\text { Buksef jorden } \\
\text { Qapiarfiup sermia } \\
\text { Taserssuaq } \\
\text { Kagssap tasia } \\
\text { Pâkitsoq } \\
\text { Laksebugt } \\
\text { Radeelv } \\
\text { Brededal } \\
\text { Daugaard-Jensens Dal } \\
\text { Angmagssalik } 1 \\
2 \\
3\end{array}$ & $\begin{array}{r}8 \\
1 \\
0 \\
17 \\
45 \\
35 \\
9 \\
35 \\
0 \\
0 \\
25 \\
10 \\
9 \\
34 \\
18 \\
6 \\
5\end{array}$ & $\begin{array}{c}0.95 \\
1.4 \\
0 \\
11.28 \\
205.7 \\
15.9 \\
30.8 \\
40 \\
0 \\
0 \\
14.5 \\
18.1 \\
10.4 \\
137.4 \\
10.0 \\
2.2 \\
2.5\end{array}$ & $\begin{array}{c}5.6 \\
8.2 \\
0 \\
4 \\
26.5 \\
2.3 \\
54 \\
4.9 \\
0 \\
0 \\
11.4 \\
20.7 \\
18.6 \\
54.4 \\
10.9 \\
8.4 \\
15.4\end{array}$ & $\begin{array}{r}0 \\
0 \\
2 \\
12 \\
1 \\
0 \\
0 \\
0 \\
5 \\
9 \\
0 \\
0 \\
0 \\
0 \\
0 \\
0 \\
0\end{array}$ \\
\hline & 257 & 500 & & 29 \\
\hline
\end{tabular}

basins, the investigations were supplemented with work on a small glacier in Buksefjord and at the Inland Ice margin at Pâkitsoq.

\section{A glaciological field and mapping programme in connection with hydropower, West Greenland}

\section{Henrik Højmark Thomsen}

As part of the GGU programme for mapping the hydroelectric potential of West Greenland, glaciological field work and glacier mapping have been started in areas proposed for local hydropower projects.

\section{Glaciological field work in Pâkitsoq}

Glaciological investigations were started on the Inland Ice north-west of Jakobshavn in August 1982. The meltwater from this part of the Inland Ice makes up a large part of the runoff from a basin which has been proposed for a local hydropower project $(\mathrm{GTO}, 1982)$. 